SCJR 14, no. 1 (2019): 1-3

\title{
Ofri Ilani In Search of the Hebrew People: Bible and Nation in the German Enlightenment
}

\author{
(Indiana University Press, 2018), $x+224$ pp.
}

\author{
AYA ELYADA \\ aya.elyada@mail.huji.ac.il \\ Hebrew University of Jerusalem, Jerusalem 9190501
}

In his book, In Search of the Hebrew People: Bible and Nation in the German Enlightenment, Ofri Ilani sets out to explore a fascinating cultural and intellectual phenomenon: the intensive and multifaceted engagement of biblical scholars, philosophers, and poets in Enlightenment Germany with the history of the ancient Hebrews (the term commonly used for biblical Israelites). That the book focuses on Germany in the second half of the eighteenth century is, of course, not a coincidence. During this time the German universities became the leading centers of European biblical scholarship. Using critical methodologies and tools from modern fields of research such as geography, anatomy, linguistics, and ethnography, German biblical scholars, headed by Johann David Michaelis, sought to distance themselves from the orthodox tradition of textual exegesis of previous generations. Instead, they sought to introduce a new kind of interpretation of the sacred Scripture: a historical-ethnographic exegesis, based on scientific, "objective" research. Moreover, during the second half of the eighteenth century, modern German nationalism began to consolidate, a process that gained clear expression in both political writings and German literature of the time. As Ilani convincingly demonstrates, important poets and philosophers of early German nationalism, most notably Johann Gottfried Herder and Friedrich Gottlieb Klopstock, adopted the ancient Hebraic model of nationhood as a poetical, cultural, and political paradigm. They located in the Bible the foundations of a particularistic nationalism, which could effectively counter the universalistic values of the French Enlightenment. This model of a Hebraic theocracy was used to justify a firm bond between religion and the public-political sphere. Moreover, these scholars and men of letters aimed to position the Hebrews as "alternative ancients," a substitute to the classical, namely Latin and Greek, models, which were identified with French philosophy and literature. 
The scholarly fields of academic biblical scholarship and of literature and philosophy were closely intertwined. They were characterized by mutual influence and fertilization, and it is not always possible to clearly demarcate the boundary between them. Together they turned the German-Christian culture of the Enlightenment era into a fertile soil for this engagement with the history of the Hebrew people, and both fields are the focus of the present book. However, Ilani does not limit himself to a detailed, comprehensive description of the main issues that stood at the center of this discourse, such as the origins of ancient Israel, the Mosaic laws, the Hebrews' poetry, and the conquest of the Land of Canaan. He further seeks to explore the meanings that were given to the story of the Hebrew people in eighteenth-century Germany within the framework of broader discussions concerning religion and statehood, war and morality, law and justice, and nationalism and ethnicity, topics which preoccupied German scholars of the time. The outcome is an interesting and insightful book, which sheds new light on a little-known chapter in the history of Christian Hebraism as well as on central concerns in the scholarly discourse of the German Enlightenment.

Ilani's book stands out for its wide scope and its thematic richness. While focusing on a clearly defined topic - writings on the Hebrew people during the German Enlightenment - the author examines every issue discussed in the book against the backdrop of broader political, social, and cultural contexts. Drawing on a rich corpus of primary sources, Ilani presents us with a thorough and original analysis of works that were written by renowned figures of the German Enlightenment, such as Herder and Michaelis, as well as by lesser-known or relatively marginal scholars of the time. The wide variety of authors and sources allows the author to explore diverse notions about the ancient history of the Hebrews that were found in Germany in the second half of the eighteenth century and to present a nuanced and insightful depiction of the discourse.

The book follows important trends in recent historical research, first and foremost, the reappraisal of the place of the Bible in the German Enlightenment. Earlier studies illustrated secularizing tendencies of the late-eighteenth century that encouraged a negative attitude toward the Bible, leading to its marginalization and even exclusion from Enlightenment culture. As opposed to this view, more recent works, such as Jonathan Sheehan's The Enlightenment Bible (2005), illustrate a continued interest in the Bible throughout the Enlightenment era, even if this interest was manifested in new approaches to interpretation. In his book, Ilani offers another example of this reappraisal by focusing on the politicalnational readings of the Bible which characterized broad circles of the German Enlightenment. This adds another layer to present-day research, which has focused on literary and cultural readings of the sacred text during the Enlightenment. Finally, this book makes an important contribution to the existing research on political Hebraism, especially with regard to the influence of the biblical story of the Hebrews on the consolidation of a national consciousness in eighteenth-century Europe. Research in this field usually focuses on England and the Netherlands during the sixteenth and seventeenth centuries and pays far less attention to Germany of the Enlightenment era. Ilani's book is undoubtedly an 
important step toward filling this lacuna. Above all, In Search of the Hebrew People is a fascinating book, and it will be of interest to scholars and lay readers alike. 